\title{
Goral Dialect as a Part of the Central European Area (on the Material of Proverbs)
}

\author{
Olga V. Raina \\ Faculty of Philology \\ St. Petersburg State University \\ St. Petersburg, Russian Federation \\ E-mail: o.raina@spbu.ru
}

\begin{abstract}
At present many research works are devoted to areal linguistic contacts. Proverbs are not studied in connection with areal typology. According to many linguistic and ethnographic researches cultural and language community exists in Central Europe. According to H.Kurzová there are several Central European language areas. In this research Goral dialect, German, Hungarian, Czech, Slovak and Slovenian are included into Central European language area. The parallels of 16 proverbs of Goral dialect were found in Central European languages. Various inner forms reflect the specific conditions of development of material and spiritual culture.
\end{abstract}

\section{Keywords-Paremiology; Goral dialect; Polish etymology}

\section{INTRODUCTION}

Dialectology, linguistic geography and arealogical researches are the consistent development of one of the areas of linguistics, namely the study of the spatial factor (areal linguistics). Using various methods, having different aims and using various sources, each of these disciplines studies the different levels of language - from phonetics to the stylistics [1].

European languages mutually influence each other. The languages are becoming typologically more similar to each other than ever have been before, when they evolved independantly from each other. Therefore linguists have long been engaged in the analysis of geographical ties of typological features of languages, as well as mutual influence of immanent and historical factors in the development of languages.

N.S.Trubetzkoy is considered to be the founder of areal typology [2]. He studied contacts between genetically distinguished families of languages and linguistic contact which has arisen from the creation of linguistic unions. These concepts rely on similarities between languages. Families of languages are treated like the groups of genetically related idioms and once a common root, which moved away from each other in their development; and it all unites together into the linguistic union only those languages that live in a specific geographic area and in which common structural qualities developed during the history and under the influence of the interference. In the article "Tower of Babel and the confusion of tongues" (1923), he suggested the concept of "language union" (the opposite of the concept of "family of languages"), which characterizes the general areal changes, which covers both genetically related and genetically unrelated languages. Thus it originates a pattern of "rainbow language network", which combines the diversity and continuity.

Modern linguistics is inherent in the increased interest in the study of regional dialects. A study carried out in different ways, but linguogeographical aspect dominates. Currently, dialect atlases are being prepared. Atlases are different according to the type of included areas in them. It may be the territory of: 1) one Slavonic language or some of its fragments (regional atlas) (Small atlas of the Polish dialects, Great Atlas of the Polish dialects), 2) a group of related languages (the Slavonic linguistic atlas, East Slavonic isoglottic lines), 3) genetically different languages (Karpathian dialectological atlas, Linguistic Atlas of Europe). The difficulty of determining the structure of the linguistic territory led to the mapping of the objects (words, morphemes and phonemes), the creation of a linguistic map or series of maps (atlas). The Slavic Linguistic Atlas consists of two series: 1.- covers vocabulary, word-formation, semantics; 2. grammar, phonetics and phonology. The object of the Slavic Linguistic is a group (family) of closely-related languages - Slavonic languages in totality, not a separate language. In the Slavic Linguistic Atlas differences within the entire Slavonic group (family) of languages are mapped which have common Slavonic meaning and which are opposed to each other. All levels of language system are represented: phonetics, phonology, morphology, syntax and vocabulary. The Slavic Linguistic Atlas is focused on the determination of isoglottic lines on the whole Slavonic territory scale, the creation of a simultaneous typology of the Slavonic dialects, which is of great value for studying the history of the Slavonic languages, the dynamics of their development, and ethnography. In the Karpathian Dialect Atlas maps give information about the vocabulary. In East Slavonic isoglottic lines dialectal features of all language levels have been reflected. The Small dialect atlas of Balkan languages edited by A.N. Sobolev is based on the ideographic principle of description of the vocabulary of the Balkan languages. Non-standard decision to create the ethno-linguistic section of the questionnaire for this atlas should be recognized as an innovative and very useful for the study of ethnolinguistic situation within the limits of the Balkan linguistic union. In all the above mentioned atlases phonetics, 
phonology, morphology and syntax are presented, but paremiology is not marked out as a separate level.

\section{The CENTRAL EURopean LinguO-CUltural AREA}

In the XX century the question was arisen about the existence of standard European-type (=eurotype) in Europe, the so-called standard average European language, or even other language unions.

Primordial thesis on Central European Union was associated primarily with the name of E. Lewy and V. Skalička and for the first time it appeared in the early 70s. E. Lewy defines the Central European area as a central one together with the term areal-word inflexion, and according to his point of view there are the German and Hungarian languages like word-inflexional languages in this area. While the Czech and Slovak languages are not a part of this area, although they are originally inflexional languages, because they are not typologically different from the Slavonic languages of the north-east [3]. In spite of it V. Skalička treats Central European and partly Balkan languages as a part of the so-called Danube language union. Along with Hungarian the Czech and Slovak languages are included in it, and partly German and Serbo-Croatian. At the same time he points to the evident independence of the historical development of these mentioned languages [4].

"The Central European Linguo-Cultural Area" is the most extensive study of Central Europe as a linguistic area by the Czech linguist H.Kurzová. According to her theory Central European language area is made up of the German, Hungarian, Czech and Slovak languages as central, Polish and Slovenian as marginal. According to H.Kurzová and S. M. Newerkla the boundaries of the language area in their relation to their individual traits are open and they are not limited only to these European languages.

If you take into consideration all the thesis and postulates of the studies of contact and areal linguistics recently, you can come to the obvious conclusion that, speaking of the Central European area, you should always keep in mind that this phenomenon has its pitfalls. On the one hand, it is often unclear what kind of geographical or cultural area can be regarded as central Europe - the criteria here are very varied. On the other hand, it is incomprehensible which languages form the Central European area, especially when the boundaries of this area in the case of individual phenomena can be extended as they should not be limited only to the contact languages belonging to this area.

According to S. M. Newerkla the position of the Polish language as the periphery of the contact area does not preclude the possibility that the Polish language, together with the German and other languages is also the center of another contact area, which is not described in detail yet [5][6][7][8]. You can apply the same to the other languages of the designated area. For example, the German language is an integral part of several areas simultaneously: besides the Central European area, it is also a part of the Baltic area [9].

First of all, clear cultural contact between the Baltic, Slavic, Hungarian, and German-speaking ethnic communities is obvious in the Central European context.

Common features in the lexicon of the contact languages are an important indicator of the intensity of both linguistic and cultural contact. If this rate is very high, it can be taken as an indication of common areal syntactical-typological features of these contact languages. Talking about the contact area, which is described by H.Kurzová [10], it may be noted that just then some "areal" traces should be distinct in the vocabulary of the languages which are included in this area. And indeed, if you will not limit the study of only German loanwords in these languages, you can clearly see the convergence of the vocabulary of Hungarian, Czech, Slovak, and partly of Slovenian, versions of the pluricentric German language, which would be marked as simplification, such as Austrian German (whereas only German in the modern eastern part of Austria or in one part of Vienna is implied by this). Also in the border regions Croatian and Polish, Ukrainian in the areas that once belonged to the Austro-Hungarian monarchy are covered by this convergent tendency.

Thus, taking into consideration the complex linguistic situation in Central Europe and the ambiguity of the concept of Central Europe, it is adequately to talk not about one Central European language area. Following H.Kurzová Goral dialect together with the German, Hungarian, Czech, Slovak and Slovenian languages is a part of the Central European language area.

\section{THE PROVERBS OF GORAL DIALECT}

The parallels of 16 goral proverbs (some of them have a few versions) were found in the above mentioned languages of Central European area by questioning informants-native speakers and in the dictionaries. Only two proverbs (one in two versions) have been found in all languages, which were investigated. One of them, according to M.Y. Kotova is included in paremiological minimum of all languages $[11][12][13][14][15]$. One proverb was found in all languages except Slovenian. All this is presented in the following table: 
TABLE I. GORAL PROVERBS AND THEIR PARALLELS IN THE LANGUAGES OF CENTRAL EUROPEAN AREA

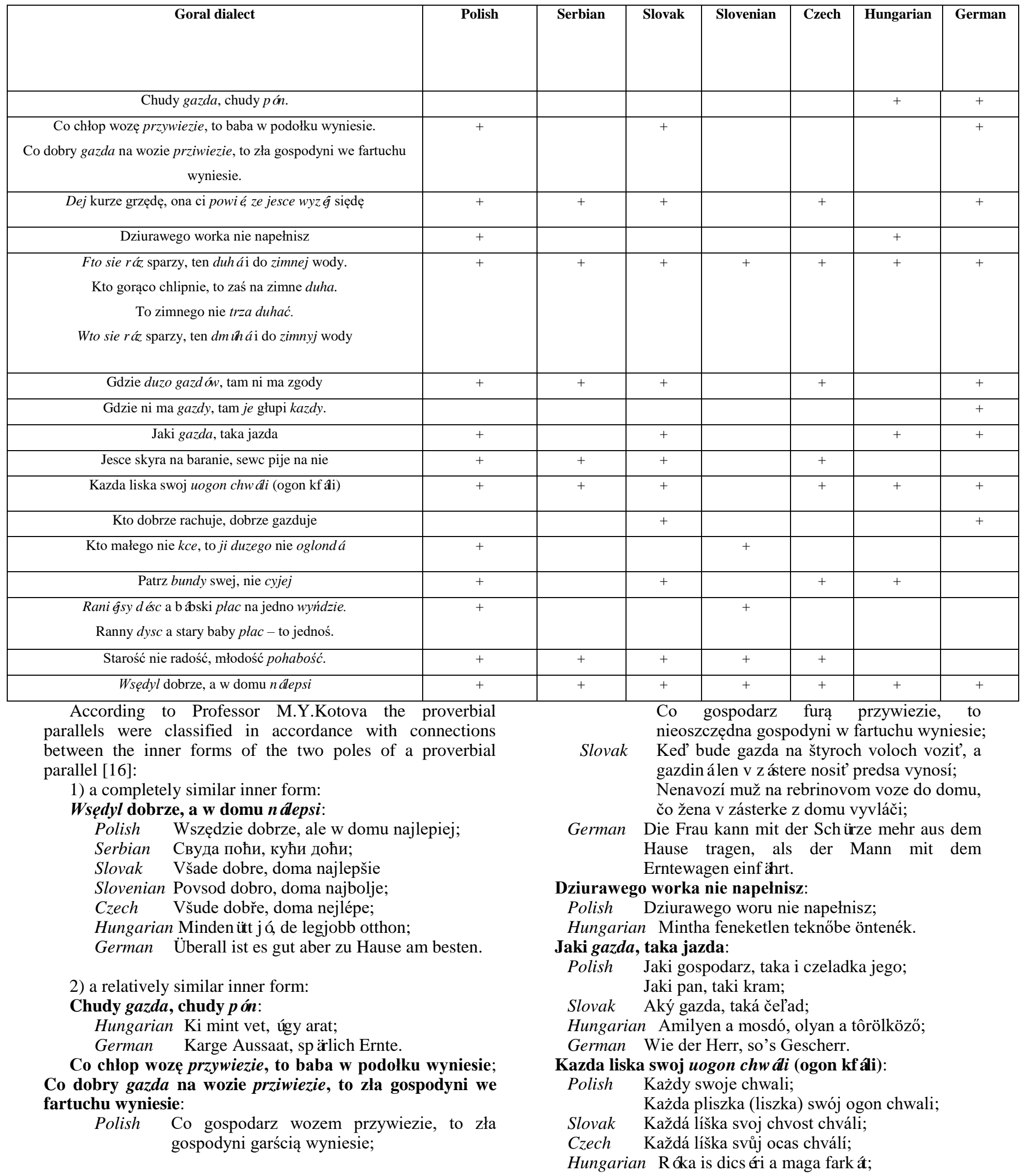


German Jedem Fuchs gefällt sein Bau.

Kto dobrze rachuje, dobrze gazduje:

Slovak Kto počtuje, ten gazduje;

German Rechnen hilft haushalten.

Kto małego nie kce, to ji duzego nie oglondá:

Polish Kto nie szanuje małego, ten niewart dużego;

Slovenian Kdor ne varuje malega, nima velikega.

Starość nie radość, młodość pohabość:

Polish Starość nie radość, młodość płochość; Starość nie radość;

Slovenian Старост није радост;

Slovak Mladost'-pochabost'; starost'-nemúdrost'; Mladost' - pochabost'; starost' - neradost'; Mladost' - radost', staroba - choroba;

Slovenian Starost ni radost. Starost - slabost;

Czech Mladost - radost; starost - žalost.

3) an absolutely different inner form:

Dej kurze grzędę, ona ci powié, ze jesce wyzéj siędę:

Polish Daj kurze grzędę, ona powie: wyżej siędę; Kurowi dano grzędę, a ona chce wieże;

Serbian Сједи козу на столицу, она ће на полицу;

Slovak Posad' žobráka za stôl, aj nohy naň vyloží;

Pust' hada do rukava, vyjde ti pod;

Czech Pust' psa pod stůl, vleze ti na stůl;

German Wenn die Schweine satt sind, stößt es den Trog um.

Fto sie ráz sparzy, ten duhá i do zimnej wody; Kto gorąco chlipnie, to zaś na zimne duha; Do zimnego nie trza duhać; Wto sie ráz sparzy, ten dmúhá i do zimnyj wody:

Polish Kto się na gorącym sparzy i na zimne dmucha; Kto się na mleku sparzy, ten na wodę dmucha;

Serbian Кога је змија уједала (су змије уједале), и гуштера (гуштерова) се боји;

Slovak Kto sa raz popálil, aj iskry sa bojí;

Kto sa raz popálil, aj l'adu sa varuje;

Koho raz had uštipne i hlísty sa bojí;

Slovenian Kdor se na vročem opeče, na mrzlo piha;

Czech Kdo se jednou spálil, bojí se i vody; Každý se spálí jen jednou;

Hungarian Kinek a meleg tej megégette a szájat, a tarhót is fújja;

German Gebrühte Katze schaut das Wasser;

Wer das Maul verbrannt hat, bläst die Suppe;

Gebranntes Kind schaut das Feuer.

Gdzie duzo gazdów, tam ni ma zgody:

Polish Gdzie kucharek sześć, tam nie ma co jeść;

Serbian дје је много бабица, дјеца су килава;

Slovak Kuchárok šest', nieto čo jest';

Czech Čím více chův, tím hưr̆e dítě dopadne;

German Viele Köche verderben den Brei.

Gdzie ni ma gazdy, tam je glupi kazdy:

German Man darf die Rechnung nicht ohne den Wirt machen.

Jesce skyra na baranie, sewc pije na nie:

Polish Jeszcze skóra na baranie, a już kuśnierz pije na nią;

Jeszcze skóra na niedźwiedziu (baranie);

Jeszcze niedźwiedź w lesie, a już skórę targują;

Serbian. Ражањ готов, а зец у шуми (гори);

Slovak Ešte koža na baranu, už mäsiari pijú na ňu;
Nepredávaj popredku kožku z medved'a;

Ešte vlka nezabili, už na jeho kožu pili;

Hungarian phraseological unit: Vki a medve bőrére iszik.

Patrz bundy swej, nie cyjej:

Polish Patrz (pilnuj) swego kożucha;

Patrz każdy swego, nie kożucha mego;

Slovak Do cudzích saní nesadaj;

Czech Nehas, když tě nepálí;

Hungarian $\mathrm{Ne}$ issd bele az orrod mások dolgába.

Raniéjsy désc a bábski płac na jedno wyńdzie; Ranny dysc a stary baby plac - to jednoś:

Polish Deszcz ranny, gniew panny i taniec starej baby niedługo trwają;

Deszcz ranny i gniew panny niedługo trwałe; Deszcz ranny i babi taniec prędko ustają;

Slovenian Ran dež - stare babe ples.

\section{CONCLUSION}

At present many research works are devoted to areal studies of language contacts. Phonemes, morphemes, lexemes are examined from the point of view of areal typology, but paremiological units are not. According to many linguistic and ethnographic researches cultural and language community is discovered in Central Europe. Following H.Kurzová, we are holding the same opinion that there are several Central European language areas. Goral proverbs (and their variants) has been compared with the languages of the Central European area.

Thus, the parallels of 16 Goral proverbs (and their variants) have been found in Central-European languages. Only two of them (one in two versions) have been found in all presented languages. One of which (Wsędyl dobrze, a w domu nálepsi) is hypothetically included in the paremiological minimum of all languages. And one was in all languages except Slovenian. Identified proverbs have been divided into three groups: a completely similar inner form (one proverb), a relatively similar inner form (eight proverbs), an absolutely different inner form (seven proverbs). Various inner forms reflect the specific conditions of development of material and spiritual culture, peculiarities of life, economics and linguistic world view.

\section{REFERENCES}

[1] Vzaimodejstviye lingvisticheskih arealov: teotiya, metodika I istochniki issledovaniya. - Leningrad, 1980. - P. 7.

[2] Trubetzkoy N.S. Vavilonskaya bashnya i smesheniye yazykov// Evrazijskij vremennik, 3. - Berlin, 1923. - P. 107-124.

[3] Lewy E. Der Bau der europäischen Sprachen (= Proceedings of the Royal Irish Academy, 48, Section C, No. 2). - Dublin: Hodges, Figgis \& Co.,1942.

[4] Skalička V. Zur mitteleuropäischen Phonologie. Časopis pro moderní filologii, 21. - 1935. - P.151-154

[5] Newerkla S. M. Language affinity in Central Europe - Some thoughts on the interrelations og German, Czech, Slovak and Magyar.//Opera slavica: Slavistické rozhledy, 10 (4). - 2000. - P.1-16;

[6] Newerkla S. M. Středoevropský jazykový areál a rakouská monarchie.//Setkání s češtinou: Sborník z konference Setkání s češtinou konané v Praze 6.-7.zář́ 2001. - Praha: Ústav pro jazyk český AV ČR, 2002. - P. 72-87; 
[7] Newerkla S. M. Kontaktareale in Mitteleuropa.//Słowiańskoniesłowiańskie kontakty językowe: Materiały z międzynarodowej konferencji naukowej zorganizowanej przez Wydział Filologii Wszechnicy Mazurskiej i Instytut Filologii Germańskiej Uniwersytetu Gdańskiego w dniach 27-28 czerwca 2005r. - Olecko: Wydawnictwo Wszechnicy Mazurskiej, 2007. - P. 29-48;

[8] Newerkla S. M. Postavenie češtiny pri sprostredkovaní germanizmov do slovenčiny (a polštiny)// Slovenská reč, 72, 2007. - P. 21-35.

[9] Kysel'ová N. Areálové vzájomné vzt’ahy slovanských jazykov centrálnej zóny. - Banská Bystrica: Univerzita Mateja Bela, 2002.

[10] Kurzová H. Mitteleuropa als Sprachareal.//Germanistica Pragensia, 13. Praha: Univerzita Karlova, 1996. - P.57-73

[11] Kotova M. Yu. Russko-slavjanskij slovar poslovits s anglijskimi sootvetstvijami / Pod red. P. A. Dmitrieva. - SPb.: Izd-vo S.-Peterb. Un-ta, 2000. - 360 p.;

[12] Kotova M. Yu., Raina O. V., Kolpakova A. A. Tetradi paremiographa. Vypusk 1: Bolgarskie poslovichnyje paralleli russkih poslovits paremiologicheskogo minimuma / Pod redaktsijej M. Yu. Kotovoj. SPb., 2013. - 240 p.;

[13] Kotova M. Yu., Sergienko O. S. Tetradi paremiographa. Vypusk 2: Czeshskie poslovichnyje paralleli russkih poslovits paremiologicheskogo minimuma / Pod redaktsijej M. Yu. Kotovoj. SPb., 2013. - 278 p.;

[14] Kotova M. Yu., Sergienko O. S., Tararaeva O. N. Tetradi paremiographa. Vypusk 3: Slovatskie poslovichnyje paralleli russkih poslovits paremiologicheskogo minimuma / Pod redaktsijej M. Yu. Kotovoj. - SPb., 2017. - 286 p.;

[15] Kotova M. Y. One Segment of the Bulgarian-English Paremiological Core. Russian Linguistic Bulletin 4(4) 2015. Yekaterinburg, 2015. 47-48 ISSN 2411-2968 (online), 2313-0288 (print). DOI: 10.18454/RULB.4.09

[16] Sergienko O.S. English and Russian Equivalents to the Proverbs of Czech Active Paremiological Fund // Russian Linguistic Bulletin. 2016. - №2 (6). - c. 76. DOI: 10.18454/RULB.6.37. ISSN 2313-0288 